„Kwartalnik Filmowy” nr 112 (2020)

ISSN: 0452-9502 (Print) ISSN: 2719-2725 (Online)

https://doi.org/10.36744/kf.553

(c) Creative Commons BY-NC-ND 4.0

\title{
Konrad Klejsa
}

Uniwersytet Łódzki

https://orcid.org/o0oo-0002-6259-9173

\section{Na jakie filmy i do których kin chadzałby Eberhard Mock? Teatry świetlne oraz ich repertuary $w$ weimarskim i nazistowskim Wroclawiu}

\author{
Slowa kluczowe: \\ kino Republiki \\ Weimarskiej; \\ kino Trzeciej Rzeszy; \\ Wrockaw
}

\begin{abstract}
Abstrakt
Książka Andrzeja Dębskiego Nowoczesność, rozryðka, propaganda. Historia kina we Wroctawiu w latach 1919-1945 (2019) jest wieloaspektową analizą kultury filmowej we Wrocławiu w okresie międzywojennym i podczas II wojny światowej. Tom pierwszy koncentruje się na kinach, ich właścicielach i architekturze, podczas gdy w tomie drugim uwaga jest kierowana na badania repertuarów i widowni historycznej. Autor recenzji krytykuje wprawdzie kompozycję książki, ale z uznaniem odnosi się do szczegółowości przeprowadzonych analiz. W szczególności zastosowana przez Dębskiego metoda POPSTAT, wymyślona przez Johna Sedgwicka, okazała się owocna w ukazaniu podobieństw i różnic pomiędzy repertuarami Wrocławia oraz ogólnoniemieckimi wynikami box-office’u.
\end{abstract}



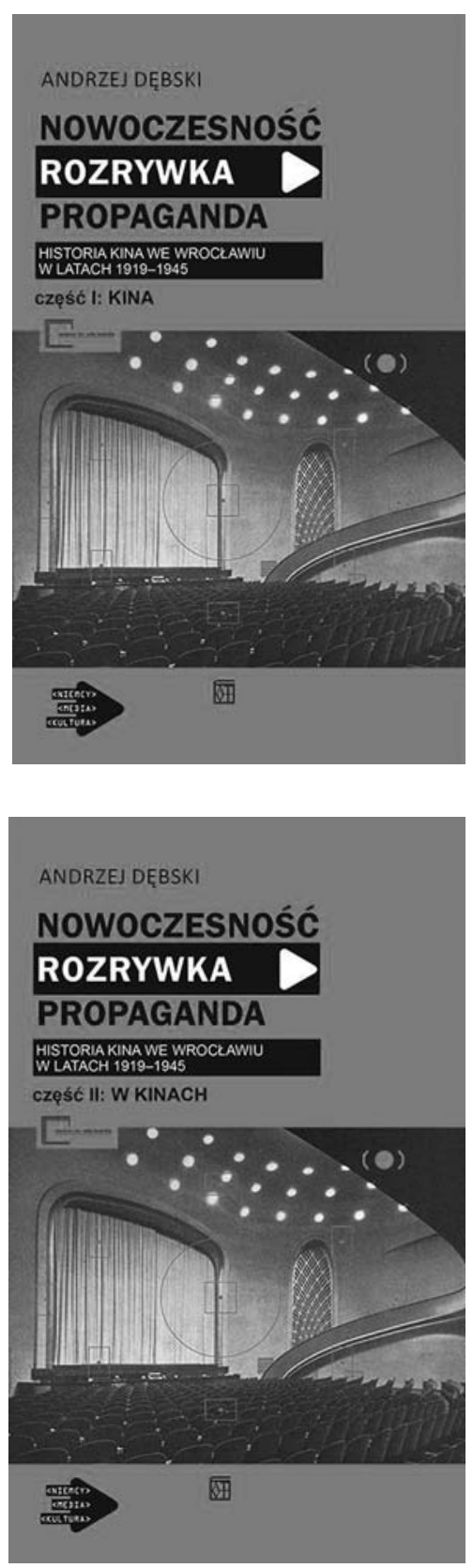

Prace badawcze Andrzeja Dębskiego należą do filmoznawstwa w wersji hard science - argumentującego nie tylko za pomocą wyrazów, ale też liczb. „Ciężar" ostatniej książki tego autora, poświęconej kinom i repertuarom niemieckiego Wrocławia w latach 1918-1945, jest zresztą jak najbardziej wymierny - została ona podzielona na dwa obszerne tomy opatrzone bardzo dużą liczbą odnośników (łącznie niemal 2200 przypisów).

Podstawą postępowania badawczego były dla Dębskiego kwerendy archiwalne i biblioteczne. Autor odwiedził - z pożytkiem dla pracy - aż 14 archiwów (nie przypominam sobie polskiej książki z zakresu historii kina, której twórca mógłby wskazać większą ich liczbę) i korzystał z prasy codziennej i branżowej z epoki (łącznie 26 tytułów). Zebranie tak obszernego materiału musiało nie tylko być czasochłonne, ale też nastręczać wielu rozterek związanych $\mathrm{z}$ analizą oraz sposobem prezentacji wyników. To zapewne dlatego rozdziały i podrozdziały nie zostały zhierarchizowane w klarowny sposób. Niektóre z nich stanowią „,interludia”, które prezentują kontekst historyczny czy teoretyczny (świetny jest na przykład podrozdział Przełom dźwiękowy w Niemczech będący wprowadzeniem do omówienia analogicznej zmiany w stolicy Dolnego Śląska) lub podejmują tematy odbiegające od głównego wątku wywodu. Tak właśnie rzecz ma się w przypadku rozdziału Wrocławskie kluby filmowe, którego częścią jest kilkustronicowy artykuł Siegfrieda Kracauera Dzisiejszy film i jego publiczność (w przekładzie Tomasza Gabisia). Dziwna to decyzja, zazwyczaj bowiem materiały źródłowe zamieszcza się $\mathrm{w}$ aneksie. Tu mamy tłumaczenie in extenso, zintegrowane $\mathrm{z}$ tekstem głównym i nieoznaczone w spisie treści. Niedostatki kompozycyjne i konstrukcyjne są wyczuwalne szczególnie w finale pracy, podzielonym na Refleksje końcowe, ciekawy Epilog (o powojennych losach dawnych właścicieli kin wrocławskich) oraz krótkie Zakończenie.

Część pierwsza rozprawy jest poświęcona kinom. W należących do niej załącznikach czytelnik odnajdzie archiwalne zdjęcia frontonów i wnętrz kin, a także kolorowe skany planów architektonicznych widowni. Jest to dodatek cenny dla historyków architektury, który jednak może cieszyć także oko laika. W tekście 
głównym Dębski poświęca najwięcej miejsca relacjom prasowym z otwarć kin; znajdują się tam także informacje, jakie filmy wyświetlano i jaki był przebieg seansów. Przykładowo: W sobotę 23 sierpnia 1919 roku otwarto kino Fledermaus-Lichstspiele przy Oklauer Stadtgraben 21, urzadzone w miejscu dawnej kawiarni Cafe Imperial. Zaprojektowane przez Alfreda Köhlera mieściło ponad 250 miejsc i orkiestrę pod kierownictwem Arnolda Ruprechta (s. 41). Dalej, na niemal 200 stronach, autor zamieszcza (według tego samego wzoru) dane dotyczące tytułów, miejsc, terminów, osób i liczb, do których dołącza mnóstwo anonsów z prasy lokalnej oraz setki odnośników do projektów architektonicznych. Tom pierwszy to niewątpliwa uczta dla wrocławianistów (ja z zainteresowaniem przeczytałem na przykład, że na otwarcie wielu kin ich właściciele zamawiali u lokalnych literatów rymowane wiersze). Gdyby Marek Krajewski zamierzał ulokować akcję nowego kryminału o Eberhardzie Mocku w środowisku wrocławskich kiniarzy, książka Dębskiego mogłaby posłużyć mu jako cenne źródło inspiracji.

Faktografia typowa dla prac z zakresu historii sztuki została w tej części uzupełniona podrozdziałami zatytułowanymi Statystyka. Porównując pięć źródeł (dwa opracowania organizacji branżowych, dwa biuletyny urzędu statystycznego oraz książki adresowe), autor rekonstruuje nie tylko liczbę kin (co jest stosunkowo proste) i miejsc (co już trudniejsze), ale także przychody brutto. Dzięki tym danym Jungbuchhalter Dębski (nie ironizuję, autor ma bowiem także wykształcenie ekonomiczne) może na przykład - w odniesieniu do cen biletów z 1927 r. - ustalić, że jeśli średnia z jednego miejsca wyniosła 89 marek, to zdecydowanie przekraczały ja kina na osi Schweidnitzer Strasse (s. 195). Oto, jakie pożytki płyną dla historyka kina ze statystyk ekonomicznych - dzięki tym obliczeniom można zrekonstruować trajektorię przechadzek kinomanów sprzed stu lat!

Dane z podrozdziałów „statystycznych” tworzą „pomost” do drugiego tomu, którego główny temat stanowią filmy. Mowa o okresie weimarskim oraz III Rzeszy, nic zatem dziwnego, że tę partię rozważań rozpoczyna świetnie pomyślany rozdział zbierający głosy krytyczne wobec słynnej pracy Od Caligariego do Hitlera (powinien on stać się obowiązkową częścią uniwersyteckich kursów z kina niemego). Ponieważ zarzuty wobec Kracauera - formułowane zrazu przez Barry'ego Salta ${ }^{1}$, a następnie przez znanych filmoznawców niemieckich - są istotne dla metody zastosowanej przez Dębskiego, przypomnijmy dwa najważniejsze. Po pierwsze: Kracauer błędnie traktuje fabuły jako premonicje, bowiem jeśli filmy mają być rodzajem barometru nastrojów społecznych, pomiar może dotyczyć wyłącznie okoliczności „tu i teraz” (w odniesieniu do filmów Republiki Weimarskiej oznacza to, że byłyby one raczej przepracowaniem traumy I wojny światowej, nie zaś „psychoanalizą nazizmu”). Po drugie: wybór filmów uznanych przez Kracauera za ważne jest zbyt arbitralny - badacz dobiera akurat takie tytuły, które pasują do jego argumentacji, a pomija inne, mogące ją podważyć. Tymczasem aby dowodzenie na podstawie korpusu było uzasadnione, musi być on zbudowany nie według własnego widzimisię, ale według dobrze sprecyzowanych kryteriów zewnętrznych, w przeciwnym razie będziemy mieli do czynienia z błędem logicznym idem per idem.

Dębski za kryterium tego, co istotne dla opisu i analizy kultury filmowej, uznaje popularność (oglądalność) filmów. Badacz historii kina rzadko ma jednak do dyspozycji wyniki box-office'u w dzisiejszym rozumieniu tego słowa, musi 
więc szukać danych na przykład w prasie branżowej. W odniesieniu do schyłku Republiki Weimarskiej za podstawowe źródło wiedzy o oglądalności Dębski - za Josephem Garncarzem² - uznaje rankingi pisma „Film Kurier” opracowane na podstawie ankiet nadsyłanych przez właścicieli kin. Zawierają one mnóstwo tytułów, zwłaszcza z obszaru kina popularnego, których próżno szukać na kartach pracy Kracauera (i wielu innych autorów powielających jego obserwacje).

To jednak dane odnoszące się do oglądalności na terenie całych Niemiec. Prawdziwa frajda dla badacza regionalnej historii kina polega na tym, by sprawdzić, czy w konkretnym mieście lub regionie wzory dystrybucyjne i preferencje widowni były podobne do ogólnokrajowych. Zazwyczaj taka praca wiąże się z koniecznością zebrania danych o programach kin (jakie filmy wyświetlano, jak często i gdzie), co jest zajęciem czasochłonnym i żmudnym, zwłaszcza jeśli trzeba się opierać na anonsach i reklamach poszczególnych kin, nie zaś na repertuarach gazetowych znanych ze współczesnej prasy. Dlatego badacze zajmujący się tak pojmowaną historią kina ograniczają się do kilkunastomiesięcznej "próbki” (u Dębskiego osobne rozdziały dotyczą sezonów 1926/1927, 1929/1930 oraz 1930/1931, a także roku 1938). Zebrane dane pozwalają na wskazanie filmów pozostających najdłużej w repertuarze ${ }^{3}$, ale też na wychwycenie informacji o filmach-kometach, które pojawiły się w programach kin na krótki czas lub znienacka. Dowiadujemy się na przykład, że w grudniu 1938 r. we wrocławskim kinie Roxy pokazywano Dziewczęta w mundurkach (Mädchen in Uniform, reż. Leontine Sagan, 1931) - film traktujący o miłości lesbijskiej, którego dystrybucja została zakazana trzy lata wcześniej. Ciekawostką dla zbieraczy poloników będzie natomiast informacja o pokazach Czarnej perły - filmu z Eugeniuszem Bodo chwalonego na łamach "Schlesische Tageszeitung".

Dębski jest pierwszym polskim autorem, który publikuje wyniki badań opartych na metodzie opracowanej przed dwiema dekadami przez Johna Sedgwicka ${ }^{4}$. Tzw. indeks POPSTAT - pozwalający w przybliżeniu oszacować popularność filmów, gdy brakuje danych z box-office'u - opiera się na pomnożeniu czasu eksploatacji filmów (tygodni, dni czy też liczby seansów), usytuowania ich w programie (jedno- lub dwuszlagierowym) oraz tzw. potencjału kina (parametr ten uzyskuje się, mnożąc liczbę miejsc przez cenę biletu, a następnie dzieląc wynik przez średni potencjał ze wszystkich kin). Rozdziały prezentujące obliczenia Dębskiego dotyczące poszczególnych sezonów zostały skonstruowane według podobnego wzoru - w podrozdziale Przepis na sukces autor przygląda się najpopularniejszym filmom, porównując je z ogólnoniemieckim rankingiem „Film Kuriera", a w Osobliwościach recepcji poświęca uwagę tym wypadkom, w których "coś się nie zgadza", np. film wyświetlano długo na ekranach premierowych, ale nie ma on wysokiego indeksu POPSTAT (co oznacza najpewniej, że obieg tej produkcji w kinach drugorzędnych był ograniczony). Przyporządkowanie tytułów do jednej ze wspomnianych kategorii nie zawsze wydaje się jasne. Przykładowo Pancernik „Potiomkin” (Bronenosets Potjomkin, reż. Siergiej Eisenstein, 1925) pojawia się w Osobliwościach recepcji, choć jego lokata na liście wrocławskiej jest zbliżona do ogólnoniemieckiej. Najważniejszy wniosek płynący z tych porównań jest taki, że we Wrocławiu popularnością większą od ogólnoniemieckiej średniej cieszyły się filmy historyczne o epoce fryderycjańskiej (zwłaszcza te, w których występował Otto Gebühr). 
Pisząc o propagandowym wymiarze filmów, Dębski dość szczegółowo omawia obowiązujący od połowy lat 20. i rozwinięty w III Rzeszy system predykatów (wyróżnień przyznawanych przez specjalną komisję), zachęcający kina do grania produkcji „wartościowych” i „szczególnie wartościowych” (system ten, oczywiście z istotnymi modyfikacjami, funkcjonuje w RFN do dziś). W Niemczech nazistowskich zachęty były związane ze stawką podatkową odwrotnie proporcjonalną do liczby filmów z predykatami w repertuarze. Uwagi te Dębski przekłada na własny materiał analityczny tylko w części, w odniesieniu do jednego z kin (jego właściciel w sezonie 1936/1937 zapłacił 9,5-procentowy podatek od rozpowszechniania, a w sezonie 1942/1943 ponad 6-procentowy, co może oznaczać powiększenie repertuaru filmów „wartościowych”). Szkoda jednak, że w książce nie ma wzmianki o korelacji predykatów z danymi repertuarowymi np. z wybranego roku wojny. Byłoby to ciekawe o tyle, że wszystkie cztery produkcje ocenione najwyżej przez system propagandy do 1944 r. (tzw. Filmy Narodu), wśród których był też niesławny Powrót do ojczyzny (Heimkehr, reż. Gustaw Ucicky, 1941), znalazły się w dorocznych „dziesiątkach” filmów najbardziej popularnych w III Rzeszy. Czy podobnie było we Wrocławiu?

O okresie II wojny światowej Dębski w ogóle pisze mniej niż o wcześniejszych dekadach (w pierwszym tomie uwagi o sytuacji kin podczas całej wojny zmieściły się na ośmiu stronach; taką samą objętość ma materiał dotyczący samego tylko 1932 r.). A szkoda, bo są to ustalenia ciekawe. O tym, że kina przynosiły w okresie wojny rekordowe przychody, wiadomo nie od dziś. Dębski podkreśla, że w latach 1943-1944 działo się tak pomimo obniżenia jakości usług - redukcji wydatków na ogrzewanie czy rezygnacji z wydawania drukowanych programów filmowych. Rozdział „wojenny” ma inny charakter niż pozostałe, również jeśli chodzi o repertuar. Nie zawiera wyliczeń POPSTAT ani porównań widowni ogólnoniemieckiej i wrocławskiej. Dębski podkreśla, że we Wrocławiu popularny był film Żyd Süß (Jud Süß, reż. Veit Harlan, 1941), o czym zaświadcza relacja prasowa $z$ uhonorowania stutysięcznego widza we wrocławskim Ufa-Palast. Przy tej okazji jednak dość niespodziewanie napomyka, że film ten pokazywano również w Krakowie. Decyzja o tym, by od czasu do czasu podzielić się jakąś informacją o repertuarze kin w Polsce (wcześniej autor pisze o recepcji Olimpady /Olympia, reż. Leni Riefenstahl, 1938/ w prasie warszawskiej), jest nie w pełni zrozumiała, choć domyślam się, że wynika z zainteresowań Dębskiego polsko-niemieckimi relacjami filmowymi ${ }^{5}$. W recenzowanych tomach uwagi o polskich kinach nie są jednak usystematyzowane ani pogłębione i pozostają bez wyraźnego związku z główną linią wywodu; sprawiają wręcz wrażenie swoistego „alibi” dla ówczesnych mieszkańców Breslau, mającego niejako wyjaśnić, że filmy Goebbelsowskiej propagandy znajdowały widzów nie tylko w III Rzeszy, ale też w miastach polskich. Nie można wykluczyć, że ta ostatnia hipoteza okazałaby się prawdziwa, jej udowodnienie wymagałoby jednak odrębnych badań.

Muszę też wspomnieć o pewnym zaskoczeniu, którego można doświadczyć już na początku lektury pracy Dębskiego. Zanim jeszcze czytelnik dotrze do części o kinach, natrafi na rozdział wprowadzający, w którym zamieszczono garść ogólnych refleksji o międzywojennym Wrocławiu. Autor przypomni nam, i słusznie, że w wyborach do Reichstagu w 1933 r. w okręgu wyborczym Breslau na NSDAP oddano ponad 50 procent głosów (czyli więcej niż w skali kraju). W dalszej części 
rozdziału pojawia się jednak specyficzny kontekst rozważań, mianowicie opinie Polaków o stolicy Dolnego Śląska. W efekcie czytelnik jest zmuszony zapoznawać się z uwagami o polityce programowej krakowskiego „Czasu”, a następnie przedzierać przez całostronicowe refleksje (zamieszczone niestety w tekście głównym, mimo że chodzi o passusy o znaczeniu ewidentnie marginalnym) o wojennej biografii jednego z jego korespondentów. Są jeszcze inne konsekwencje tej decyzji autora: otóż o „zażydzeniu” międzywojennego Wrocławia przeczytamy w opinii cytowanego przez Dębskiego polskiego korespondenta, o tym zaś, co o mniejszościach pisała niemiecka prasa lokalna, nie sposób będzie się z tak pomyślanego wstępu dowiedzieć. Uważam, że taki sposób ujęcia problemu jest niezbyt fortunny, choćby z tego powodu, że kieruje uwagę ku sprawom zgoła niezwiązanym $\mathrm{z}$ tematyką monografii.

Formułuję te kilka uwag krytycznych w poczuciu, że książka Dębskiego jest praca, z którą warto dyskutować. Niewątpliwie stanowi ona ważne osiągnięcie naukowe, pod wieloma względami pionierskie, będące efektem wnikliwych prac kwerendalnych, wyróżniające się na tle rodzimych prac filmoznawczych. Oby w ślad za tą pracą pojawiły się kolejne, analizujące repertuary kin polskich.

Andrzej Dębski, Nowoczesność, rozrywka, propaganda. Historia kina we Wrocławiu w latach 1919-1945, Atut, Wrocław 2019.

\footnotetext{
${ }^{1}$ Jedną z pierwszych prac krytycznych wobec przemyśleń Kracauera Barry Salt opublikował w 1979 r. na łamach "Sight and Sound"; w Polsce ukazała się ona w 2015 r. w „Kwartalniku Filmowym” (B. Salt, Od Caligariego do...?, tłum. M. Żurawski, „Kwartalnik Filmowy" 2015, nr 89-90).

2 J. Garncarz, Hollywood in Deutschland. Zur Internationalisierung der Kinokultur 1925-1990, Stroemfeld, Frankfurt am Main 2013.

${ }^{3} \mathrm{Na}$ ten temat zob. np. W. Świdziński, Co było grane? Film zagraniczny w Polsce w latach
}

1918-1929 na przykładzie Warszawy, Wydawnictwo IS PAN, Warszawa 2015.

${ }^{4}$ Zob. J. Sedgwick, C. Pafort-Overduin, Znajomość zachowań widowni na podstawie danych statystycznych: Londyn i Amsterdam w połowie lat 30. XX wieku, tłum. A. Cybulski, M. Rawska, w: Filmowa Europa: dawniej i dziś, red. M. Pabiś-Orzeszyna, M. Rawska, P. Sitarski, Wydawnictwo UŁ, Łódź 2019.

${ }^{5} \mathrm{~W}$ drodze do sasiada. Polsko-niemieckie spotkania filmowe, red. A. Dębski, A. Gwóźdź, Atut, Wrocław 2013.
Konrad Klejsa
Profesor Uniwersytetu Łódzkiego pracujący w Katedrze Filmu i Mediów Audiowizualnych. Jego zainteresowania naukowe ogniskują się wokół historii polskiej kultury filmowej po II wojnie światowej, polsko-niemieckich relacji filmowych oraz badań widowni. Obecnie kieruje projektem Rozpozszechnianie filmóz w PRL, finansowanym przez Narodowe Centrum Nauki. 


\section{Bibliografia}

Dębski, A. (2019). Nowoczesność, rozrywka, propaganda. Historia kina we Wrocławiu w latach 1919-1945. Wrocław: Atut.

Dębski, A., Gwóźdź, A. (2013). W drodze do sasiada. Polsko-niemieckie spotkania filmowe, Wrocław: Atut.

Garncarz, J. (2013). Hollywood in Deutschland. Zur Internationalisierung der Kinokultur 1925-199o. Frankfurt am Main: Stroemfeld.

Salt, B. (2015). Od Caligariego do...? (tłum. M. Żurawski). Kwartalnik Filmowy, (89-90), Ss. 114-127.

Sedgwick, J., Pafort-Overduin, C. (2019). Znajomość zachowań widowni na podstawie danych statystycznych: Londyn i Amsterdam w połowie lat 30. XX wieku (thum. A. Cybulski, M. Rawska). W: M. Pabiś-Orzeszyna, M. Rawska, P. Sitarski (red.), Filmowa Europa: dawniej $i$ dziś (ss. 203-223). Łódź: Wydawnictwo UŁ. http://dx.doi.org/10.18778/7969-572-0.09

\author{
Keywords: \\ Weimar cinema; \\ Third Reich \\ cinema; \\ Wrocław; \\ Breslau
}

\begin{abstract}
Konrad Klejsa

What Films and in Which Cinemas Would Eberhard Mock Have Watched? Cinema Theatres and Their Programming in Weimar and Nazi Breslau

In his book Nowoczesność, rozrywka, propaganda. Historia kina we Wrockawiu w latach 1919-1945 [Modernity, Entertainment, Propaganda: History of Cinema in Wrocław in the Years 1919-1945] (2019), Andrzej Dębski offers a multi-layered analysis of cinema culture in Breslau in the interwar period and during World War II. Volume I of the monograph focuses on movie theatres - their architecture and owners, whereas in Volume II the attention shifts to cinema programming and film audiences. While the reviewer is critical of the structure of Dębski's book, he appreciates the meticulousness of research. In particular, Dębski's use of John Sedgwick's POPSTAT method proved to be fruitful in demonstrating the similarities and differences between the programming in Breslau's cinemas and nationwide box-office results in the Weimar Republic and the Third Reich.
\end{abstract}

